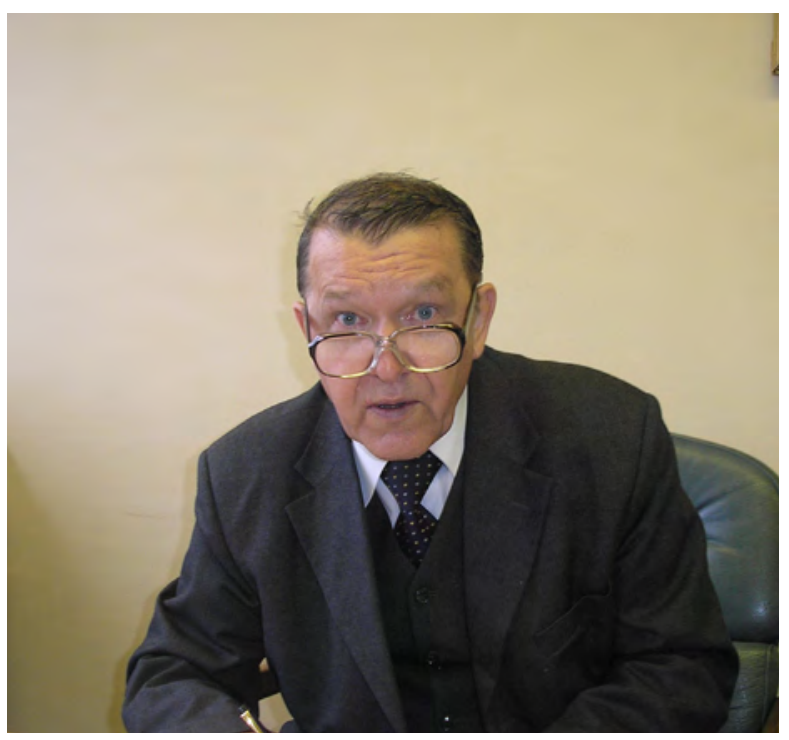

А.В. Леденев. Н.З. Кольичова

Вспоминая Альберта Петровича Авраменко

кабинета заведуюшего, когда преподаватель или студент заглядывал на кафедру истории русской литературы XX века в середине 2000-х. Кафедрой с 2002 по 2013 год заведовал Альберт Петрович, сумевший привнести в привычную череду академических забот атрибуты радостной одушевленности и ненатужной праздничности. Профессор филологического факультета МГУ имени М.В. Ломоносова Авраменко почти всегда покорял собеседника или слушателя с первых мгновений знакомства - тем, с каким видимым удовольствием делал свою преподавательскую работу, как радовался общению с коллегами (а для него к числу коллег относились и ровесники-профессора, и студенты-первокурсники), как обаятельно улыбался, встречая любого из них. К тому же Альберт Петрович обладал выразительной внешностью, был строен и спортивен: и в 70, и в 75 лет он сохранял «белогвардейскую» выправку, «королевскую» отточенность учтивых жестов, легкость «летящей» походки.

Стилизуя фоносемантические штудии Андрея Белого, о поэзии которого Альберт Петрович написал кандидатскую диссертацию, можно было бы сказать, что инициал имени и последняя литера фамилии профессора при ретроспективном мнемоническом охвате его личности ассоциируются не только с границами алфавита (альфой и омегой), но и с эмоциональной оценочностью междометий - тех самых, что идут в ход в ситуации признания особого статуса человека в нашей иерархии знакомств, или мгновенной сердечной солидарности с проявлениями его радости или скорби, или, что еще важнее, в ситуации лирической «невыразимости», когда музыка важнее риторики. Ну, а если обойтись без ассоциативных «символистских» туманностей, то тем, кому приходилось слышать лекции Авраменко, наверняка запомнились медлительные, намеренно медлящие, тянущиеся, протягивающиеся «о» и «а» в любимом Альбертом Петровичем стихотворении «царскосельского лебедя» И.Ф. Анненского: «“Не правда ль, больше никогда / Мы не расстанемся? довольно?..” / И скрипка отвечала да, / Но сердцу скрипки было больно».

O «траурной», изобилующей не столько ликующими «просветами», сколько «бездонными провалами» поэзии русского символизма Альберт Петрович говорил тонко и точно, не настаивая на «букве» собственных формулировок, но заражая самим духом «со-чувствования» и «со-творчества». А главное впечатление от его лекций, которое формировалось и логикой типологических построений, 
и тембром голоса профессора, заключалось в том, что мир, как учил Владимир Соловьев, «не может быть спасен насильно», что для «русского мира», вероятно, спасительной окажется сама любовь к поэзии и что Серебряный век - пусть и в особом метаисторическом смысле - не завершился и, Бог даст, никогда не завершится. Эту свою веру, оборотной стороной которой было прочное филологическое знание, он выражал, истолковывая творчество А. Блока, выросшее из русской классики XIX века (об этом написана его докторская диссертация), или обращаясь к «наследникам Серебряного века», среди которых особенно близок ему был - по тонкому взаимодействию «проговариваемого» и «несказанного», «оркестра» и «шепота», «лирики» и «иронии» - Булат Окуджава.

Альберт Петрович любил с благодарностью вспоминать своих учителей - Бориса Васильевича Михайловского и Алексея Георгиевича Соколова. Не без оттенка лукавой назидательности он рассказывал коллегам, как первый из них вернул ему, тогда еще студенту второго курса, машинопись курсовой работы, испещренную многочисленными пометками и уточнениями. В разговоре о дорогих ему людях или близких его сознанию примерах профессионализма, мастерства и артистизма он не боялся высоких слов, даже патетики, но при этом у слушателя не возникало чувства неловкости - вероятно, потому, что Авраменко всегда был искренним. Внимательно читал статьи и книги не только коллег по кафедре, но и «соседей по цеху» - «теоретиков», русистов-лингвистов, «зарубежников». И обязательно благодарил их за те филологические открытия и находки, которыми они его одарили. В этом, вероятно, сказывались генетически унаследованные им от предков дары дворянской благосклонной терпимости, благодарной отзывчивости, щепетильной заботы о хорошем настроении окружающих.

Великолепно чувствовал аудиторию - не просто откликался на ее вербализованные просьбы или подразумеваемые желания, но и предвосхищал их. Однажды на лекции в рамках курса по литературе Серебряного века вдруг задал вопрос: «А вы понимаете, в чем смысл толстовства? Вы понимаете, что оно значило для образованных людей начала века? Рассказать?». «Да!» - шумно выдохнула аудитория, и профессор тут же, отвлекаясь от непосредственной темы разговора, прочитал емкую лекцию о сути учения Толстого - с обширными цитатами, которые, казалось, не озвучивал, а дегустировал. Приводил он их почти всегда по памяти, предваряя особенно важные фрагменты своим излюбленным «Слушайте!»: торжественно поднимал вверх указательный палец, как будто не столько призывая других услышать, сколько вслушиваясь сам в то, что сейчас прозвучит, - и это всякий раз звучало ошеломительно свежо и убедительно.

Доброжелательность и искренняя открытость собеседнику - любому, даже малознакомому - сочетались в нем со сдержанностью, которая, безусловно, была проявлением самоуважения, неотделимого от уважения к другим, - с чуткостью к тому, что в английской культуре соотносится с понятием privacy, а в отечественной традиции ассоциируется с подлинным благородством, аристократизмом духа. Таким он и запомнился всем нам, сотрудникам кафедры «XX века», - аристократом духа. Всегда вставал при появлении дамы - и в этом не было театрального наигрыша или нарочитого позирования: было видно, что он делал это не задумываясь, просто потому, что иначе и не мог.

Свое знаменитое «Здравствуйте, красавица!» он произносил настолько искренно, что каждая «красавица» не могла не поверить этой оценке: она понимала, что так обращается профессор Авраменко именно к ней. А для Альберта Петровича 
было не так важно, кто перед ним, - профессор или первокурсница. Да что там первокурсница! Однажды он поприветствовал так трехлетнюю дочку своей сотрудницы, пришедшую с мамой на работу. Дело было летом, и девочка была в шортиках, футболке и с хвостиком на макушке, что не помешало ей почувствовать себя и красавицей, и аристократкой: она важно кивала в ответ на слова приветствия, обращенные к ней: «Здравствуйте, красавица! Спасибо за то, что вы почтили нас своим присутствием!» Поразительно, что в этих словах не было ни привычного в обращении к маленьким детям театрального «сюсюканья», ни даже тени «умудренной» иронии, - это было нормальным для Альберта Петровича проявлением добра, которое в его сознании всегда связывалось со светлой, жизнеутверждающей интонацией, с мажорным «голосовым» сопровождением.

При всей своей доброте и открытости к общению он избегал фамильярности, а особенно не выносил «административных восторгов», казенного церемониала, дежурного, показного интереса к предмету разговора - и стеснительно морщился при малейших признаках чинопочитания или иной неискренности в поведении собеседника или оппонента. Он был поистине демократичен: легко вовлекался в спор, будь то научный диспут или просто обсуждение недавно прочитанной книги (в том числе и беллетристики - он был открыт всему), с нескрываемым удовольствием, с поощряющей улыбкой слушал доводы собеседника, даже если был не согласен с ним.

«И это прекрасно!» - такой фразой он, как правило, подводил черту в разговоpe - и произносить эти слова Альберт Петрович умел с разной интонацией: то с оттенком самоиронии (дескать, вы ждете от меня каких-то заключительных слов и даже знаете, какими они будут, - так вот, получите, пожалуйста), то с подлинным восхищением чем-то или кем-то, то с легкой и необидной насмешкой над собеседником, впавшим в неумеренные восторги, но чаще всего - с искренним желанием «продлить очарование» самой ситуации общения, пригласить собеседника разделить радостную веру в то, о чем кратко и убедительно сказал Александр Блок: «Сотри случайные черты - / И ты увидишь: мир прекрасен».

Сведения об авторах: Александр Владимирович Леденев, докт. филол. наук профессор филологический факультет МГУ имени М.В. Ломоносова

Alexander V. Ledenev, Doctor of Philology Professor Philological Faculty Lomonosov Moscow State University

Наталья Зиновьевна Кольцова, канд. филол. наук доцент

кафедра истории новейшей русской литературы и современного литературного процесса филологический факультет МГУ имени М.В. Ломоносова 
Natalia Z. Koltsova,

$\mathrm{PhD}$

Associate Professor

Philological Faculty

Lomonosov Moscow State University

\section{REMEMBERING ALBERT AVRAMENKO}

